UDC 821.163.41.09 Njegoš P. P. II

https://doi.org/10.18485/ms_zmss.2021.99.22

Горан Радоњић

Филолошки факултет Универзитета Црне Горе

gmradonjic@yahoo.com

Goran Radonjić

University of Montenegro, Faculty of Philology

gmradonjic@yahoo.com

\title{
ЊЕГОШЕВА ОБРАДА ПРИЧЕ О БАТРИЋУ ПЕРОВИЋУ
}

\author{
NJEGOŠ'S TREATMENT OF THE STORY \\ ABOUT BATRIĆ PEROVIĆ
}

У раду се анализирају начини на који се у Горском вијениу Петра II Петровића Његоша трансформише прича о Батрићу Перовићу чији се структурни модел издваја на основу неких њених варијанти у епским пјесмама. Његош једну епску причу претвара у тужбалицу, уводећи нови лик Батрићеве сестре и проблематизујући ритуални карактер тог жанра. Успоставља се веза и са трагедијом освете као жанром. Та епизода се посматра у контексту Горског̄ вијениа и тумаче се неки њени аспекти који се тичу интегрисања текста, грађења идентитета и политичких импликација.

Кључне ријечи: Његош, Горски вијенаи, модел епске приче, тужбалица, идентитет.

The paper analyzes the ways in which the story about Batrić Perović is transformed in The Mountain Wreath by Petar II Petrović Njegoš, the story whose structural model is examined on the basis of some of its variations in epic poems. Njegoš transforms an epic story into a lament, introducing a new character of Batrićs sister and questions the ritual character of the genre. A relation with the tragedy of revenge as a genre is established. The episode is observed in the context of The Mountain Wreath, and some aspects concerning the integration of the text, constructing of identity and political implications are interpreted.

Key words: Njegoš, The Mountain Wreath, model of epic story, lament, identity.

Епизода са сестром Батрићевом у Горском вијениу често се посматра с обзиром на однос Петра II Петровића Његоша према тужбалици као жанру. Тако ће, рецимо, за тужбалицу сестре Батрићеве Оксана Микитенко рећи да је „садржајно и стилски <... смештена у оквир традиције народних песама“" (Микитенко 2014: 538), мислећи прије свега на конвенције тужбалице. Уочава се „не само утицај, него често истоветност на идејно-филозофском и светогледном нивоу, али и на нивоу тематике, садр- 
жаја, стилистике и композиције, интонационо-емотивне експресивности и поетске изражајности“ (Исто). Можда је извор таквом посматрању Вуково запажање да се ,за цијело може казати да овдје нема ни једне ријечи коју покајнице у Црној Гори нијесу говориле“ (Караџић 1972: 107). А и изнутра гледано, из самог текста, намеће се таква перспектива. У једном типу тужбалице, као лирске обредне пјесме, по јавној улози и идејном усмјерењу уочава се, сматра Пешић, сродност са епском пјесмом: „Оплакивањем покојника слави се његова улога у борби и истичу националноослободилачки и друштвени идеали средине“ (Пешић 1996: 246).

И због те повезаности, а и у контексту Његошевих дјела, као важан се показује и однос према епској традицији. У Оїлеgалу срйском, готово на самом почетку, једна иза друге налазе се пјесме „Освета Батрића Перовића“, уз коју иде у загради одређење „око 1700. год“, и пјесма „Српски Бадњи вече“, за коју се каже „око 1702. год“ (Његош 2006а). Тиме се, уз вријеме збивања, јасно сугерише и још једна, двострука веза међу тим пјесмама. С једне стране, оне су извори за Горски вијенац. ${ }^{1}$ Са друге стране, оне су повезане истим мотивима - заробљавања, откупа и освете, који се у првој пјесми односе на Батрића Перовића, а у другој на владику Данила.

Мотив заробљавања и откупа јунака стари је мотив, и један његов извор је, очигледно, у стварности, и није везан само за наше крајеве (сјетимо се, рецимо, да је и Сервантес имао сличну судбину), а могло би се тражити и његово митолошко извориште и значење.

Његош је, очигледно, ставио те двије пјесме у Огллеgало срйско са јасном идејом да ће се оне упоређивати са начином на који су њихови мотиви обрађени у Горском вијениу.

Прича $^{2}$ о Батрићу Перовићу може се посматрати не само као прича о судбини неког поједница, него као једна варијанта типичне приче која се може свести на основне структурне елементе. Модел те епске приче је: отмица, нуђење откупа, одбијање понуде, убиство, освета.

Показатељ да су у питању типске ситуације јесте, рецимо, пјесма „Јован Бакић и Осман Ћоровић“, 3 у којој се даје врло слична варијанта те приче, и гдје је негативац исти, али функцију Батрића Перовића добија Јован Бакић. Може се, дакле, посматрати слично ономе како Владимир Проп посматра бајку - у питању су функције које се могу приписати различитим ликовима. Са друге стране, ту причу можемо видјети и као један општи модел којим се стварност, или њен дио, сазнаје и представља.

1 Стихове из Горског̄ вијенца наводићу према: Његош 1978, а консултовао сам и: Његош 2005.

2 Термин прича узимам у наратолошком значењу, као наративни садржај, низ догађаја, не у жанровском смислу, разумије се.

3 За све епске пјесме, осим оних из Ог̄леgала срйског̄, користим сајт „Monumenta Serbica“"В. Детелић и Томић. 
Самим тим, онда, извор те приче није судбина неког конкретног појединца, Батрића Перовића, него је то модел за један аспект свијета, и помоћу њега се успостављају појмови у којима се разумије и читава стварност.

Наћи ћемо ту причу у разним варијантама. Рецимо, њене елементе имамо у пјесми „Бановић Страхиња“, гдје дервиш саопштава како га је бан пустио из заточеништва уз обећање да ће да донесе откуп - дервиш ту прије свега осјећа грижу савјести што није одржао ријеч. Не само да бану дервиш не замјера због девет година ропства, јер је према њему људски поступао и пустио га на вересију, него му даје вјеру да га неће одати, чак и кад би овај побио пола турске војске! Њихово пријатељство и побратимство веће је од непријатељства између Срба и Турака уочи Косовског боја. У таквој причи, дакле, узима се као природно отети неког и тражити за њега откуп, док је прекршај не донијети откуп, или не прихватити да се неко за откуп ослободи.

Судбина Батрића Перовића дата је у варијантама: „Перовић Батрић“ из четврте Вукове збирке, „Перовић Батрић“ и „Опет Перовић Батрић“ из четврте књиге Срйских нароgних ӥјесама из необјављених рукойиса

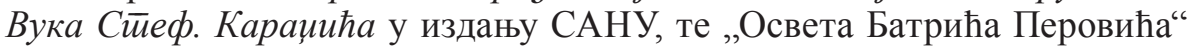
из Његошевог Оіллеgала срӣског̄. Можемо им, с обзиром на структуру, додати и пјесму „Јован Бакић и Осман Ћоровић“ из четврте књиге издања САНУ. Свака од варијанти почиње in medias res, цвили заробљени јунак (нема предисторије, како и зашто се нашао у ропству), затим тражи да буде пуштен на откуп, нудећи благо, побратимство, чак некад и кумство, али антагониста све то одбија, било самоиницијативно, било на нечији наговор, те заточеника погуби он сам, или неко његов. Породица за то сазнаје, па брат, самоиницијативно или након прекора оца или мајке, креће да се освети. Након тога се понавља ситуација са почетка, али са другачијим улогама: антагониста сад нуди откуп, побратимство или и кумство, али бива одбијен, па га осветник погуби. У варијантама се јавља контекстуализацуја тог модела, додају се неки елементи који усмјеравају значење текста. То је прича о смрти, о освети, и прича о заједници и вриједностима које ту заједницу чине.

У Горском вијениу тај се епски модел трансформише у један лирски облик, у тужбалицу. Постижу се ефекти структуралне, естетске и идеолошке природе. Кључна промјена је увођење новог лика, сестре Батрићеве, којој се повјерава да говори о братовљевој погибији. Та трансформација открива још један потенцијал те приче, блискост једном моделу трагедије, а то је трагедија освете. Код Његоша се већ у Ог̆леgалу срйском може уочити извјесно помјерање. Наиме, наслови варијанти код Вука („,Перовић Батрић“ два пута и „Опет Перовић Батрић“) наглашавају да је то прича о судбини насловног јунака, а наслов варијанте из Оеллеgала срйског̄ („Освета Батрића Перовића“) ставља у фокус посљедицу јунаковог страдања, нешто што неко други треба да учини. 
Промјеном жанра Његош активира многе значењске потенцијале тужбалице. Најприје, само тужење, јер оно „није само женски одговор на смрт: оно настаје из односа читаве заједнице према смрти, па сходно томе - и према животу““ (Шијаковић 2011: 73). Самим тим се ствара веза са вриједностима које су у основи идентитета. Тужбалица је и средство да се испрати покојник на други свијет, а и начин да се он очува у памћењу. Зато се покојник описује, даје му се, могло би се рећи, дефинитивна карактеризација, облик који ће се чувати у сјећању, и који ће се евоцирати у каснијим тужбалицама, као што се и у тој која је посвећена њему помињу и други покојници.

Тужећи, жена доспијева у једно „транзитно стање“, и у њему повређује себе, чупа косу, гребе лице, удара груди. „Овакав призор на посматрача свакако оставља снажан утисак и истиче ту црту тужилице као медија између живих и покојних: она је перципирана као неуравнотежена услед бола, чак луда и опасна по себе и друге“ (Шијаковић 2011: 74). Истовремено, сама тужбалица се схвата „не само као неконтролисани емотивни испад, већ и као средство којим се изразито тешке емоције каналишу, вентил ка коме се оне усмјеравају, чиме се управо избјегавају лудило и (само)деструктивност. Овај катарзични, конструктивни и терапеутски потенцијал тужења веома је важан и близак граничном, демаркационом аспекту тужбалице као моста између живих и мртвих“ (Шијаковић 2011: 75). Пјевање је ту начин да се сама тужилица, а преко ње и сви ожалошћени, изборе са болом због губитка, и начин да се тај бол савлада, да се настави даље са животом.

Тужбалица може имати и осветнички карактер. Када постоји јасан кривац за смрт, „тада га тужбалица неизоставно помиње, проклиње, и неријетко присутне мушке рођаке подстиче на одмазду“ (Шијаковић 2011: 76).

Његош ту активира везу и са још једним жанром која потенцијално постоји у тужбалици: „Наравно да је тужбалица уплетена у трагедију, у ту умјетност преокупирану смрћу: крвопролићем, жртвом, осветом“ (Шијаковић 2011: 73). У питању су три врсте текста, припадају трима књижевним родовима, епици (епска пјесма), лирици (тужбалица) и драми (трагедија), али се показује да међу њима постоји повезаност.

У Горском вијениу прича о Батрићу Перовићу претвара се у причу о сестри Батрићевој и о њеном позиву да се заједница освети. То је и, на извјестан начин, врхунац трансформације основне приче: структурно гледано, она, пролазећи кроз разне варијанте, од приче о односу између два лика, заточеника и његовог мучитеља, постаје све општија прича: о односу између двије породице, између два племена, и, најзад, у Горском вијениу, између двије заједнице. ${ }^{4}$ Сваку реализацију тог наративног језгра

4 Ту, наравно, мислим на структурални редослијед у уопштавању, који се не мора поклапати са редослиједом како су варијанте биљежене. 
можемо разумјети као неку врсту преговарања са друштвеним институцијама и праксама. Другим ријечима, у различитим контекстима користи се исто наративно језгро, мијења се, развија и допуњује, и, као резултат преговарања са друштвеним институцијама и праксама, настају различите верзије.

Однос између два племена у првом је плану у верзији из четврте Вукове књиге, гдје „Враг донесе од Тупана Панта“. Он се појављује када је изгледало како Осман може пристати на Батрићев предлог о откупу: „одиста га Осман пуштит шћаше“.

Ој Турчине, Ћоровић-Османе!

Немој пуштит' Перовић-Батрића:

Што ти даје небројено благо,

Узео је благо од Турака:

Што л' ти даје седам џевердара,

С таки' их је скинуо Турака;

Што ти даје в’јенце и обоце,

Он ће наше снахе поватати,

Те ће скидат' в’јенце и обоце;

Што ти даје Цуцкињу робињу,

То ће моју ћерку заробити

Те је дати засе у откупа:

Што ти даје коња големога,

Тај је коњиц родом из Бањана.

Панто описује Батрића као отимача и зликовца, пријетњу по њих све, као племе, као заједницу. Важно је да „ни племенска припадност ни непријатељство према Батрићу не потиру разлике између Панта и Османа, нити поништавају хијерархију која произлази из њихових различитих друштвених и верских позиција““(Pavlović 2014: 289). Могло би се онда закључити да за Панта „племенска раван представља суштински, највиши оперативни ниво идентификације и распознавања заједничких интереса, и хоризонт његовог деловања““ (Pavlović 2014: 290).

Тумачити се може и другачије: Панто настиоји gа ирикаже како

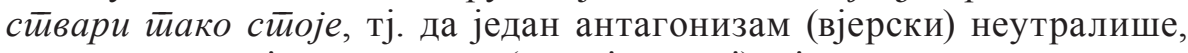
а да нагласи своју припадност (старој и новој) заједници и да пресудним представи други антагонизам, племенски. Примијетимо како Панто започиње обраћање Осману са „Ој Турчине“ — што је знак суштинске разлике међу њима, па и антагонизма, јер га означава као некога ко је дио завојевача, непријатеља. Затим Панто преко снаха уводи идеју крвног сродства и припадности „нашима“, а то „наши“ значи - припадници истог племена. Тако међусобну разлику и антагонизам минимизира, а истиче да је заједништво главно. На крају, као својеврсни додатни аргумент, Панто потеже то што је коњ „родом из Бањана“ — ваљда сугеришући како племенска припадност чини заједништво, а њега ваља схватити као највишу вриједност која обухвата све, чак и животиње. Уочава 
се и комика у том потезању рода коме коњ припада, као и у томе како Панто коња о ком говори Батрић назива прво „големим“, а одмах затим „коњицом“ (опет, како изгледа, у намјери да „раскринка“ Батрића). То је и гротеска, јер неко ко и са коњем успоставља некакву заједницу „по роду“" не осјећа баш никакву повезаност са Батрићем — штавише, он сам убија Батрића. Необично је то убиство, као што је необично и да, ако је Батрић такав каквим га Панто представља, Осман то већ не зна. Има разлога да Пантов говор и поступак видимо прије свега као сопствено доказивање припадности: раскида веза са Батрићем и Батрићевом заједницом, а учвршћивања веза са Османом и његовом заједницом. Зато Пантова порука Осману суштински каже не само да је Осман, мада се приклонио Турцима, и даље припадник истог племена као и Панто, већ да преко племенске припадности Панто остаје у заједници са Османом, па преко њега дијелом почиње да припада и Турцима.

Иако та верзија Панта приказује као Батрићевог убицу, нико у пјесми њега не види као кривца - нити се тражи његова смрт, нити ће Осман, рецимо, помињањем правог убице покушати да се извуче из опасности. Панто се даље ни не помиње. Можемо то разумјети и као својеврсну слабост те верзије, али и као знак да, без обзира на то проширење основног обрасца, тема те приче јесте кривица оног који зароби јунака и који је прекршио конвенцију о откупу. Најзад, Осман је дозволио и прихватио то убиство, али потенцијално има и ширу кривицу, јер је турска окупација и створила опште услове да такве ситуације, па и Пантов злочин, буду могуће.

У Горском вијенцу позив родитеља сину да се освети (јер то му је дужност), претвара се у позив сестре заједници и главарима да се освете. То је зато што Батрић више није само син и брат, нити само припадник једног племема (Цуца), него виђени и типични представник свог народа.

Батрић се веома индивидуализује, и слика се као оличење идеала. Важан је и сам начин на који се гради индивидуални идентитет, тј. које се особине наглашавају као кључне за човјека. Вук Мићуновић (који је и сам дат као једно од оличења идеала, јер, како каже „мнозина“, „и збори и твори! / Српкиња га јошт рађала није/ од Косова, а ни пријед њега“ ст. 392-394) описује Батрића (гдје се наглашава паралелизам између два лика):

Онаквога сивога сокола

Црногорка јошт рађала није!

Не могаше човјек нигда знати

ал' је згоднй али је ваљастй

ал’ је мудрй али је љубавни!

(1980-1985)

Важан квалитет је и што је Батрић „очи гвозденијех“ (у боју), какве Мићуновић није видио ,у једнога момка“. Више главара се смјењује у похвалама, и један од ефеката је конструисање идентитета. 
Сестра жали прије свега због начина на који је Батрић погинуо:

Да погибе у бој љути, убојниче,

ђе се српски момци грабе, младо момче,

око главах и оружја, просте ране;

но на вјеру у невјере, вјерна главо!

$(1932-1934)$

Изостављају се елементи из модела приче - нема понуде за откуп, одбијања, погубљења, него се помјерањем нагласка на освету истиче кључна димензија Горског̄ вијениа.

Вук Томановић, након што и сам похвали Батрића, како је свакога Црногорца већ претекао јунаштвом, мада је „само настао“, тј. тек рођен, проблематизује освету, питајући која је корист од ње. То је један моменат који истиче Стивен Гронблат: „сваки постигнути идентитет увек у себи има знакове сопственог подривања или губитка“ (Гринблат 2011: 29). Кнез Јанко одговара:

Како зашто? Што говориш, чоче?

Да га могу добро осветити, ка̂ да би га из гроба дигнули!

$$
\text { (2016-2018) }
$$

По особинама, Батрић Перовић представља лик идеалног мушкарца. Зато је једна од порука те епизоде да најбољи страдају на превару, и да таква судбина пријети свима. Опасност је стална и налази се свугдје.

Као и у двије пјесме из Оіллеgала срйског̄, у Горском вијениу гради се аналогија између владике Данила и Батрића: владика је замало настрадао на исти начин као Батрић („,спуштавао се на уже“). То је знак да иста судбина може задесити свакога, јер то нису случајности, него манифестације сталне и свеопште борбе. Зато сестра Батрићева говори о томе да ће „по бедему од Травника“ Батрићева глава „много браће наћи“.

Глава у Травнику сугерише да то није зло које долази ни од личне, ни од породичне свађе, нити чак од племенског сукоба, већ је то зло које је наручено из даљине, из једног од центара непријатељског дјеловања. Тако се у двије епизоде са женама (сестром Батрићевом и бабом) дају и два зла која дјелују ка Црној Гори: једно долази из Травника, друго из Скадра, оба потичу од везира који тамо столују.

У вези је то и са ужасном мишљу са којом Његош живи, коју помиње Андрић у есеју „Његош као трагични јунак косовске мисли“ (види: Андрић 1977: 14): 
Црни брче, гдје ћеш окапати

Дал’ у Мостар или у Травнику?

(види: Андрић 1977: 22)

Аналогија постоји, дакле, и са самим Његошем, и са Његовим временом. Како каже Мишел Обен: „Све што нам оно (дјело Горски вијенаи - Г. Р.) приказује с почетка Данилове владавине може се применити и на Његошево доба““ (Обен 2013: 235).

Трансформација епског модела омогућава да се изгради нова ситуација. Онда се успоставља однос са претходном и наредном сценом у Горском вијениу, као и са сном који је сањао кнез Бајко, Батрићев дјед, а који он сам схвата као најаву „братске погибије“ (стих 1370).

Сестра Батрићева иде са покајницама „уз поље“ и тужи (пјева), као што у претходној сцени иду сватови „уз поље“ и пјевају. Али, било да је збивање у знаку Ероса, било да је у знаку Танатоса, суштина је иста, антагонизам према Турцима, агон, борба. Тако се сватови и њихове пјесме претварају, на једном нивоу, у такмичење и супротстављање јунака из различитих традиција, а на другом нивоу то постаје мотивација за однос главара према (како каже Вук Мићуновић),„Бранковићима и лижисаханима“" Црногорцима који су пошли у турске сватове. Тако ће за војводу Станка то бити знак да је сукоб неминован и близу:

Чудне бруке, грдне мјешавине!

Чујасте ли како се појаше?

Залуду се недружина друже, све некакви приговори стари:

Милош, Марко - Мујо и Алија!

Приправља се, док одједном пукне;

већ превире кӓпа на све стране.

$(1886-1892)$

Након епизоде са сестром Батрићевом слиједи епизода са бабом „пророчицом“" из Бара. Испоставља се да је њу послао скадарски везир да „помути“ Црногорце.

Између осталог, те епизоде прилог су енциклопедичности Горског вијенца, и то не само у смислу да је та књига „енциклопедија црногорског живота и црногорске историје“ (Деретић 1996: 233), него и у бахтиновском - то је енциклопедија жанрова и стилова. Оне дају и мотивацију за увођење и другачије врсте стиха у односу на доминантни десетерац, у сватовској пјесми о Фатими и у тужбалици.

Епизодом са сестром Батрићевом, као и епизодама непосредно претходом и сљедећом, доприноси се и интеграцији текста, и појединачно посматрано, а и у међусобној вези. Показује се да су то само наизглед неповезане сцене, и само наизглед не доприносе заплету, јер веза је ту тематска, аналошка. То је донекле слично ономе како функционише, рецимо, 
Шекспиров Хамлет, са паралелним збивањима међу којима се успостављају везе у равни тематике. Готово све што се приказује у Горском вијениу у знаку је антагонизма према Турцима, и, у крајњој линији, директно од њих изазвано. Готово све што се дешава и о чему се говори, од судбине Европе и пропасти српског царства, па до небеских прилика, сујевјерја и снова - у знаку је тог антагонизма, и аргумент је за доношење одлуке о истрази. И кад је свадба, она се претвара у сукоб, и кад је сахрана, она се претвара у позив на освету, на борбу. У том смислу још једном се потврђује као тачно Деретићево запажање да „сваки део Горског̄ вијенца представља Горски вијенаи у малом, јер на посебан начин изражава оно што Горски вијенаи својом целином значи, сваки је део особен вид те целине, њено огледало“ (Деретић 1996: 161).

Павле Поповић каже да та истрага, као прво ослобођење Срба од Турака, има велики значај, јер: „Пре тога догађаја, Црна Гора не представља један народ него једну гомилу племена, гомилу братстава, без везе међусобне, без идеје заједничке“ (Поповић 2000: 24). Епизода са сестром Батрићевом показује да се то заједништво не постиже само истрагом, него и идејом освете Батрића Перовића. То зато што схватити потребу да се он освети значи постати свјестан да си народ који је угрожен и који се мора бранити. ${ }^{5}$

5 Павловић коментарише како се кроз варијанте епске пјесме о Батрићу Перовићу конструише одређена политика Његоша и уопште породице Петровића, повезујући то са политиком српске епике. „Под појачаним утицајем политичког центра, у овом раздобљу поље српске епике захвата, у шмитовском смислу, један од оних снажних политичких тренутака када је непријатељ, у конкретној стварности, препознат и именован“ (Pavlović 2014: 303). Поставља затим и низ питања, међу којима: „да ли је било неизбежно да усмена традиција буде повезана са оваквом политиком и да постане њен извор? <...> Да ли је могуће повезати српску епику са радикално другачијом концепцијом политике, била она либерална или, што би можда било посебно продуктивно, са реконфигурацијом политичког поља кроз концепт пријатељства, оцртаном у Дери-

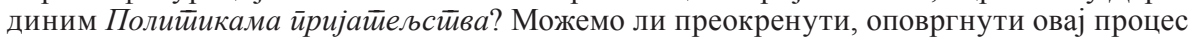
поновним откривањем усмене традиције без тог талога?“ (Исто). Могу се таквом приступу дати различите примједбе. Најопштије, уочљиво је да се ту наша епика посматра са становишта једне (савремене) политике, и да се та политика покушава наметнути не само као исправна и пожељна за садашњост, него и као исправна алтернатива једној конструисаној верзији некадашње политике. Са друге стране, ту другачију концепцију политике не треба посебно тражити, јер она већ постоји и код Његоша и у српској епици, она је заправо њен неодвојиви дио - то је не само политика пријатељства, него и братства. Наведимо још једном одломак из писма скадарском везиру Осман-паши, које и Андрић цитира (јер то се може видјети и као Андрићева политика, ако се таква политика уопште треба тражити), у есеју о Његошу као трагичном јунаку косовске мисли: „Када са мном говориш како мој брат Бошњак, ја сам твој брат, твој пријатељ, али када говориш као туђин, како Азијатин, како непријатељ нашега племена и имена, мени је то противно и свакоме би благородно мислећему човјеку противно било“ (Његош 2006б: 183). Тако и у пјесми „Србин Србима на части захваљује“: „,Ко би бјежа од оваквог добра / и од таквог братског пријатељства?“ Сјетимо се и пријатељства Страхин-бана и дервиша непосредно пред Косовски бој. А и у првој пјесми Оёлеgала срйског̄, „Синови Иванбегови“, као што знамо: „брат је мио које вјере био/када братски чини и поступа;/али они братски с нама неће/већ крвнички, по турском начину!“ Наша је „општа 
У Горском вијениу прави се још једна важна измјена у односу на традицију: самоубиство сестре која нариче за братом. То у први план ставља однос између поезије и дјеловања, живота. Његош прави једну кардиналну измјену у жанру тужбалице. Умјесто терапеутског дејства пјевања и чувања у сјећању, гради се сцена у којој поезија више нема ту моћ: сестра узима нож Батрићевог дједа, па нож који би могао да буде средство освете симболично убија њу. Затим страда и кнез Бајко. Тако њих двоје и сами постају жртве турског зла, које и саме траже освету. То је још један ритуални моменат у тој сцени.

Стављање ритуалног у први план могло би бити објашњење за донекле проблематичан реалистички статус. Наиме, ако би се и могло узети као увјерљиво да једно за другим иду таква збивања, остаје питање шта бива са покајницама, а и са сестром Батрићевом и кнезом Бајком: јављају ли главари икоме шта се догодило, чине ли нешто поводом тога итд. „Свак ћути и плаче“, али се разговор наставља, најприје о сестри и Батрићу (не и о Бајку), а онда долазе „стотине“ Озринића, Цуца (Батрићевих) и Бјелица, па се прелази на нову епизоду, гдје ће се убрзо сви смијати због писма попа Мића. Према томе, конвенционалност књижевног текста долази до изражаја, али и ритуални карактер те сцене.

Тужбалица ту не може имати терапеутско дејство зато што Батрићева смрт није дата као питање личног или породичног губитка, него као питање опстанка заједнице. Зато начин да они не само доживе катарзу него и да уопште преживе јесте — да се боре.

\section{ЛИТЕРАТУРА}

Андрић Иво. Умет̄ник и њег̄ово gело: Есеји II. Андрић Иво. Сабрана gела. Књ. 13. Београд - Загреб - Сарајево - Љубљана - Скопје: Просвета - Младост - Светлост - Државна заложба Словеније - Мисла, 1977.

Гринблат Стивен. Самообликовање у ренесанси: og Мора gо Шексиира. Превеле Невена Мрђеновић и Јелна Стакић. Београд: Clio, 2011.

Деретић Јован. Комӣозиција „Горског̄ вијенца“. Подгорица: Октоих, 1996.

Детелић и Томић: http://www.monumentaserbica.branatomic.com/epp/index.php. Приступљено 10. априла 2021.

Караџић Вук Стефановић. Еӣног̄рафски сйиси. Караџић Вук Стефановић. Сабрана gела. Књ. XVII. Београд: Просвета, 1972.

Микитенко Оксана. „Његошева тужбалица сестре Батрићеве: 'Овдје нема ниједне ријечи коју покајнице у Црној Гори нијесу говориле’ (Вук Караџић)“. Њег̄ощи у своме времену и gaнас. Т. 2. 43. научни састанак слависта у Вукове дане, Београд, 12-15. IX 2013. Београд: Међународни славистички центар, 2014: 531-541.

Његош Петар II Петровић. Горски вијенаи. Београд: Српска књижевна задруга, 1978.

Његош Петар II Петровић. Горски вијенаи: крийичко изgање: йекстиолог̄ија. Подгорица: ЦИД, 2005.

несрећа“, дакле, друге врсте, како каже Његош у истом писму: „до када ће се она моја браћа од своје рођене браће туђити <...> и до када ће за туђу корист работати не сјећајући се себе ни својега“" 
Његош Петар II Петровић. Ог̄леgало срӣско. Његош Петар II Петровић. Сабрана gјела. T. VI. Подгорица: Октоих - Јумедиа монт, $2006 \mathrm{a}$.

Његош Петар II Петровић. Проза. Изабрана йисма. Из биљежнице. Превоgи. Његош Петар II Петровић. Сабрана gјела. T. VII. Подгорица: Октоих — Јумедиа монт, 20066.

Обен Мишел. Горски вијенац. Превео Живојин Живојиновић. Ломпар Мило (ур.). Кғиг̄a o Њег̄oüy. Београд: Српска књижевна задруга, 2013: 204-284.

Пешић Радмила. „Тужбалица“. Пешић Радмила, Милошевић Ђорђевић Нада. Нароgна

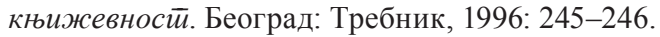

Поповић Павле. О Њег̄ощy. Поповић Павле. Сабрана gела. Књ. VIII. Приредио Ненад Љубинковић. Београд: Завод за уџбенике и наставна средства, 2000.

Шијаковић Ђурђина. „Обликовање бола: античка грчка тужбалица и њен терапеутски

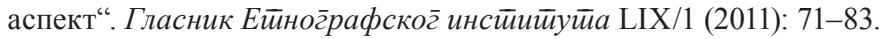

Pavlović Aleksandar. Epika i politika: Nacionalizovanje crnogorske usmene tradicije u prvoj polovini XIX veka. Beograd: Biblioteka XX vek, 2014.

\section{LITERATURE}

Andrić Ivo. Umetnik i njegovo delo: Eseji II. Andrić Ivo. Sabrana dela. Knj. 13. Beograd - Zagreb - Sarajevo - Ljubljana - Skopje: Prosveta — Mladost — Svetlost — Državna založba Slovenije - Misla, 1977.

Grinblat Stiven. Samooblikovanje u renesansi: od Mora do Šekspira. Prevele Nevena Mrđenović i Jelna Stakić. Beograd: Clio, 2011.

Deretić Jovan. Kompozicija „Gorskog vijenca“. Podgorica: Oktoih, 1996.

Detelić i Tomić: http://www.monumentaserbica.branatomic.com/epp/index.php. Pristupljeno 10. aprila 2021.

Karadžić Vuk Stefanović. Etnografski spisi. Karadžić Vuk Stefanović. Sabrana dela. Knj. XVII. Beograd: Prosveta, 1972.

Mikitenko Oksana. „Njegoševa tužbalica sestre Batrićeve: 'Ovdje nema nijedne riječi koju pokajnice u Crnoj Gori nijesu govorile' (Vuk Karadžić)“. Njegoš u svome vremenu $i$ danas. T. 2. 43. naučni sastanak slavista u Vukove dane. Beograd, 12-15. IX 2013. Beograd: Međunarodni slavistički centar, 2014: 531-541.

Njegoš Petar II Petrović. Gorski vijenac. Beograd: Srpska književna zadruga, 1978.

Njegoš Petar II Petrović. Gorski vijenac: kritičko izdanje: tekstologija. Podgorica: CID, 2005.

Njegoš Petar II Petrović. Ogledalo srpsko. Njegoš Petar II Petrović. Sabrana djela. T. VI. Podgorica: Oktoih — Jumedia mont, $2006 \mathrm{a}$.

Njegoš Petar II Petrović. Proza. Izabrana pisma. Iz bilježnice. Prevodi. Njegoš Petar II Petrović. Sabrana djela. T. VII. Podgorica: Oktoih - Jumedia mont, $2006 \mathrm{~b}$.

Oben Mišel. Gorski vijenac. Preveo Živojin Živojinović. Lompar Milo (ur.). Knjiga o Njegošu. Beograd: Srpska književna zadruga, 2013: 204-284.

Pavlović Aleksandar. Epika i politika: Nacionalizovanje crnogorske usmene tradicije u prvoj polovini XIX veka. Beograd: Biblioteka XX vek, 2014.

Pešić Radmila. „Tužbalica“. Pešić Radmila, Milošević Đorđević Nada. Narodna književnost. Beograd: Trebnik, 1996: 245-246.

Popović Pavle. O Njegošu. Popović Pavle. Sabrana dela. Knj. VIII. Priredio Nenad Ljubinković. Beograd: Zavod za udžbenike i nastavna sredstva, 2000.

Šijaković Đurđina. „Oblikovanje bola: antička grčka tužbalica i njen terapeutski aspekt“. Glasnik Etnografskog instituta LIX/1 (2011): 71-83. 
Goran Radonjić

NJEGOŠ'S TREATMENT OF THE STORY ABOUT BATRIĆ PEROVIĆ

\section{Summary}

The paper analyzes the ways in which the story about Batrić Perović is transformed in The Mountain Wreath by Petar II Petrović Njegoš, the story whose structural model is examined on the basis of some of its variations in epic poems. That epic story could be reduced to a model: capture, ransom offer, refusal of the offer, murder, revenge. Every realization of that model would be a negotiation with social conventions and practices.

Njegoš transforms an epic story into a lyrical form, a lament, introducing a new character of Batrić's sister and examines the ritual character of the genre. Great potential of lament is thus activated, and also questioned. A relation with the tragedy of revenge as a genre is established. The episode is observed in the context of The Mountain Wreath, and some aspects concerning the integration of the text, constructing of identity and political implications are interpreted.

Key words: Njegoš, The Mountain Wreath, model of epic story, lament, identity. 